\title{
Efektivitas Pendidikan Kesehatan Reproduksi Berbasis Seluler pada Calon Pengantin terhadap Peningkatan Pengetahuan Kesehatan
}

\author{
Ade Tyas Mayasari ${ }^{1}$, Moh Hakimi ${ }^{2}$, Umu Hani EN ${ }^{3}$, Winny Setyonugroho ${ }^{4}$ \\ ${ }^{1}$ Fakultas IImu Kesehatan Universitas 'Aisyiyah Yogyakarta \\ ${ }^{2}$ Fakultas Kedokteran, Kesehatan Masyarakat dan Keperawatan, Universitas Gadjah Mada \\ ${ }^{3}$ Fakultas IImu Kesehatan Universitas 'Aisyiyah Yogyakarta \\ ${ }^{4}$ Fakultas Kedokteran dan Ilmu Kesehatan Universitas Muhammadiyah Yogyakarta \\ Korespondensi: ade.tyas93@gmail.com,wsetyonugroho@umy.ac.id
}

Submisi: 29 Juni 2019; Revisi: 20 April 2020; Penerimaan: 22 April 2020

\begin{abstract}
Background: Every individual needs to know about the issues of sexuality and reproduction before marriage so the reproduction health education is important to give to the prospective bride and groom. Technology-based education is an innovative pathway for providing health information. Objective: to determine the effectiveness of reproduction health education on the improving of knowledge of the prospective bride and groom.

Method: Quasi-Experimental research with pretest posttest in Non-equivalent Control Group Design. The data were obtained from a knowledge questionnaire filled out by the prospective bride and groom. This research was conducted at KUA (the Civil Registry Office) Mlati and Gamping, Sleman Regency.

Results and Discussion: There was an increase in the average posttest score of knowledge in each group. Based on the results of the data analysis, it was found that the respondents who were given reproduction health education through cellular experienced a greater increase in the post-test score (the difference between the average pretest and post-test score is 5.67) compared to the group who were not given reproduction health education via cellular (the average difference between the pretest and post-test score is 2.2 ). The Cellular-based reproduction health education significantly ( $p$ value $=0.00$ ) influences the prospective bride and groom's knowledge of the reproduction health.

Conclusion: Cellular-based reproduction health education can improve the knowledge of the prospective bride and groom about the reproduction health.
\end{abstract}

Keywords: Reproduction Health; Cellular; Knowledge; Premarital.

\section{ABSTRAK}

Latar Belakang: Setiap individu perlu mengetahui tentang isu-isu seksualitas dan reproduksi pada masa pranikah, sehingga pendidikan kesehatan reproduksi menjadi penting untuk diberikan kepada calon pengantin. Pendidikan berbasis teknologi merupakan jalur inovatif untuk pemberian informasi kesehatan.

Tujuan: mengetahui efektivitas pendidikan kesehatan reproduksi terhadap peningkatan pengetahuan pada pasangan calon pengantin.

Metode: Penelitian eksperimental semu (Quasi Experiment) dengan pretest postest pada Non-equivalent Control Group Design. Data diperoleh dari kuesioner pengetahuan yang diisi oleh pasangan calon pengantin. Penelitian ini dilakukan di KUA Mlati dan Gamping, Kabupaten Sleman.

Hasil dan Pembahasan: Terjadi peningkatan skor rata-rata postest pengetahuan pada masing-masing kelompok. Berdasarkan hasil analisis data didapatkan bahwa responden yang diberikan pendidikan kesehatan reproduksi melalui seluler mengalami peningkatan nilai postest dengan selisih rata-rata pretest postest sebesar 5,67 dibandingkan dengan kelompok yang tidak diberikan pendidikan kesehatan reproduksi melalui seluler dengan selisih rata-rata pretest postest sebesar 2,2. pendidikan kesehatan reproduksi berbasis seluler secara signifikan $(p$ value $=0,00)$ mempengaruhi peningkatan pengetahuan calon pengantin terhadap kesehatan reproduksi.

Kesimpulan: Pendidikan kesehatan reproduksi berbasis seluler dapat meningkatkan pengetahuan pasangan calon pengantin tentang kesehatan reproduksi.

Kata kunci: Kesehatan Reproduksi; Seluler; Pengetahuan; Calon Pengantin 


\section{PENDAHULUAN}

Setiap individu perlu mengetahui tentang isuisu seksualitas dan reproduksi pada masa pranikah, sehingga pendidikan kesehatan reproduksi menjadi penting untuk diberikan kepada calon pengantin. ${ }^{1}$ Seksualitas yang merupakan bagian dari kesehatan reproduksi menjadi suatu kebutuhan semua orang, baik muda maupun tua tanpa memandang gender. ${ }^{2}$ Peraturan Direktur Jendral Bimbingan Masyarakat (BIMAS) Islam Kementerian Agama Nomor 373 Tahun 2017 menginstruksikan bahwa setiap lakilaki dan perempuan yang akan melangsungkan pernikahan harus mengikuti bimbingan perkawinan atau kursus pranikah yang diselenggarakan oleh Kementerian Agama. ${ }^{3}$

Program Bimbingan Perkawinan merupakan suatu program sebagai upaya untuk meningkatan ketahanan keluarga sehingga dapat meminimalkan angka perceraian. ${ }^{4}$ Faktor penyebab perceraian bermacam-macam, diantaranya adalah perselisihan, gangguan pihak ketiga, tidak adanya keharmonisan, sikap suami yang meninggalkan kewajiban serta adanya Kekerasan Dalam Rumah Tangga (KDRT). Pendidikan pranikah adalah suatu pendekatan dan pencegahan untuk menghindari ketidakpuasan seksual dalam kehidupan suami istri. Permasalahan yang selama ini sering muncul tentang kesehatan reproduksi bagi wanita adalah kurangnya dukungan dalam proses kehamilan, persalinan, nifas dan pemilihan alat kontrasepsi. $^{5}$

Pendidikan berbasis teknologi merupakan jalur inovatif untuk pemberian informasi kesehatan. ${ }^{6}$ Secara global, penggunaan ponsel semakin cepat pada kalangan kaum muda. Satu dari dua warga di negara berkembang memiliki telepon seluler. $^{7}$ Penggunaan telepon seluler juga dapat dimanfaatkan untuk memberikan pendidikan kesehatan. Aplikasi kesehatan berbasis seluler atau Mobile Health (mHealth) memiliki peluang besar sebagai salah satu intervensi yang efektif untuk meningkatkan kesehatan masyarakat. ${ }^{8}$ Memberikan materi pendidikan kesehatan seksual yang akurat, komprehensif dan terkini melalui smartphone dapat membantu meningkatkan kesadaran perilaku seksual berisiko serta meningkatkan hasil kesehatan seksual dan reproduksi yang lebih baik. ${ }^{9}$
Penelitian tentang inovasi pendidikan kesehatan reproduksi berbasis seluler kepada calon pengantin belum banyak dilakukan, sehingga penelitian ini perlu dilakukan untuk mengetahui efektivitas pendidikan kesehatan reproduksi berbasis seluler untuk meningkatkan pengetahuan tentang kesehatan reproduksi pada pasangan calon pengantin.

Tujuan penelitian ini yaitu untuk mengetahui efektivitas pendidikan kesehatan reproduksi berbasis seluler bagi calon pengantin terhadap peningkatan pengetahuan pada pengantin baru.

\section{METODE}

Desain penelitian yang digunakan pada penelitian ini adalah eksperimental semu (Quasi Experiment). Rancangan penelitian yang digunakan adalah Non-equivalent Control Group Design dengan pretest postest. Populasi penelitian ini adalah pasangan calon pengantin yang terdaftar di KUA Mlati dan Gamping pada bulan Maret-April 2019.

Subjek penelitian ini adalah pasangan calon pengantin yang memenuhi kriteria inklusi dan eksklusi yang telah ditetapkan oleh peneliti. Kriteria inklusi penelitian ini adalah Pasangan Usia Subur (PUS) yang telah terdaftar di KUA Mlati dan Gamping, memiliki smartphone pribadi, bersedia untuk berpartisipasi dalam penelitian ini, belum pernah menikah sebelumnya, bagi responden wanita belum pernah hamil dan melahirkan sebelumnya. Kriteria eksklusi penelitian ini adalah Pasangan Usia Subur (PUS) yang berusia $<17$ tahun dan $>45$ tahun, tidak dapat berkomunikasi dengan baik, tidak mengisi kuesioner pretest postest serta form konfirmasi sebanyak dua kali berturut-turut. Berdasarkan data yang diperoleh dari KUA dan sesuai dengan kriteria penelitian didapatkan jumlah responden sebanyak 30 responden pada kelompok intervensi (calon pengantin yang terdaftar di KUA Mlati) dan 30 responden pada kelompok kontrol (calon pengantin yang terdaftar di KUA Gamping).

Pemberian intervensi pendidikan kesehatan reproduksi melalui pesan whatsapp dilakukan selama dua minggu dengan interval setiap dua hari sekali dan dalam sehari diberikan sebanyak dua kali 
yaitu pagi (pukul 08.00 atau 09.00) dan sore hari (pukul 18.00 atau 19.00). Pemberian pendidikan kespro dalam satu forum yang dilaksanakan selama dua hari (sesuai jadwal bimbingan perkawinan yang telah ditetapkan oleh kemeterian agama pada masing-masing KUA). Setelah diberikan pretest dan pendidikan kespro, baik melalui pesan whatsapp maupun kelas pranikah, dilakukan follow up sampai empat minggu setelah pernikahan. Setelah empat minggu dilakukan follow up, kemudian dilakukan postest. Setelah data pretest dan postest terkumpul, dilakukan analisis data.

Penelitian ini telah dilengkapi oleh surat keterangan layak etik dari komisi etik penelitian Universitas Yogyakarta yang tertanggal 26 Januari 2019.

\section{ANALISIS STATISTIK}

Analisis data yang digunakan pada penelitian ini adalah uji Wilcoxon dan Mann-Whitney karena data tidak menunjukkan distribusi normal. Nilai $p<0,05$ didefinisikan sebagai hasil yang signifikan pada penelitian ini.

\section{HASIL DAN PEMBAHASAN}

Tabel 1 menunjukkan distribusi frekuensi karakteristik responden. Dari tabel 1 dapat dilihat bahwa responden pada kelompok intervensi dan kontrol mayoritas berada pada rentang usia 2035 tahun yaitu masing-masing sebanyak 29 orang (58\%) dan 21 orang (42\%). Dilihat dari pendidikan terakhir, kelompok intervensi dan kontrol mayoritas berpendidikan SMA/Sederajat atau Perguruan Tinggi, yaitu 28 orang (50,9\%) dan 27 orang $(49,1 \%)$. Karakteristik pekerjaan, responden pada kedua kelompok (intervensi dan kontrol) mayoritas bekerja, dengan jumlah yaitu 29 orang $(52,7 \%)$ dan 26 orang (47,3\%). Karakteristik responden dalam hal mendapatkan informasi kesehatan reproduksi sebelumnya, responden kelompok intervensi mayoritas belum pernah mendapatkan informasi mengenai kespro sebelumnya yaitu sebanyak 21 orang $(65,6 \%)$ dan pada kelompok kontrol mayoritas responden sudah pernah mendapatkan informasi mengenai kespro sebelumnya yaitu sebanyak 19 orang $(67,9 \%)$.

Tabel 1.Karakteristik Responden

\begin{tabular}{|c|c|c|c|c|c|c|c|}
\hline \multirow{2}{*}{\multicolumn{2}{|c|}{$\begin{array}{l}\text { Karakteristik Responden } \\
\qquad(\mathrm{n}=30)\end{array}$}} & \multicolumn{2}{|c|}{ Kelompok Intervensi } & \multirow{2}{*}{\multicolumn{2}{|c|}{$\begin{array}{c}\text { Kelompok Kontrol } \\
\%\end{array}$}} & \multirow{2}{*}{ Total } & \multirow{2}{*}{$\%$} \\
\hline & & $\%$ & $(n=30)$ & & & & \\
\hline \multirow[t]{3}{*}{1.} & Usia & & & & & & \\
\hline & $<20$ atau $>35$ tahun & 1 & 10 & 9 & 90 & 10 & 100 \\
\hline & $20-35$ tahun & 29 & 58 & 21 & 42 & 50 & 100 \\
\hline \multirow[t]{3}{*}{2.} & Pendidikan & & & & & & \\
\hline & SD atau SMP & 2 & 40 & 3 & 60 & 5 & 100 \\
\hline & SMA atau PT & 28 & 50,9 & 27 & 49,1 & 55 & 100 \\
\hline \multirow[t]{3}{*}{3.} & Pekerjan & & & & & & \\
\hline & Tidak Bekerja & 1 & 20 & 4 & 80 & 5 & 100 \\
\hline & Bekerja & 29 & 52,7 & 26 & 47,3 & 55 & 100 \\
\hline \multirow[t]{3}{*}{4.} & Mendapat Informasi & Sebel & & & & & \\
\hline & Belum Pernah & 21 & 65,6 & 11 & 34,4 & 32 & 100 \\
\hline & Sudah Pernah & 9 & 32,1 & 19 & 67,9 & 28 & 100 \\
\hline
\end{tabular}


Tabel 2. Nilai Rata-Rata Pretest Postest Pengetahuan

\begin{tabular}{|c|c|c|c|c|c|c|c|c|}
\hline \multirow[b]{2}{*}{ Variabel } & \multicolumn{3}{|c|}{ Pretest } & \multicolumn{2}{|c|}{ Postest } & \multirow[b]{2}{*}{$\begin{array}{c}\text { Mean } \pm \\
\text { SD }\end{array}$} & \multirow{2}{*}{$\begin{array}{c}\text { Selisih } \\
\text { Rata-rata } \\
\text { Pretest } \\
\text { Postest }\end{array}$} & \multirow{2}{*}{$\begin{array}{c}P \\
\text { value }\end{array}$} \\
\hline & Min - Max & Median & Mean \pm SD & Min - Max & Median & & & \\
\hline Intervensi & $6-21$ & 15 & $\begin{array}{c}15,00 \pm \\
3,582\end{array}$ & $19-21$ & 21 & $\begin{array}{c}20,67 \pm \\
0,606\end{array}$ & 5,67 & \multirow{2}{*}{0,000} \\
\hline Kontrol & $12-19$ & 2,006 & $\begin{array}{c}15,67 \pm \\
2,006\end{array}$ & $14-20$ & 18 & $\begin{array}{c}17,87 \pm \\
1,358\end{array}$ & 2,2 & \\
\hline
\end{tabular}

Tabel diatas menunjukkan bahwa ada peningkatan nilai rata-rata pada kedua kelompok. Selisih nilai rata-rata pretest postest pengetahuan pada kelompok intervensi adalah sebesar 5,67. Selisih nilai rata-rata pretest postest pengetahuan pada kelompok kontrol sebesar 2,2. $P$ value pada hasil pretest postest pengetahuan kelompok intervensi dan kontrol adalah $p$ value $=0,000$, artinya bahwa pendidikan kesehatan reproduksi berbasis seluler dan kelas pranikah dapat meningkatkan pengetahuan kesehatan reproduksi pada calon pengantin.

Tabel 3. Nilai signifikansi karakteristik terhadap pengetahuan

\begin{tabular}{lc} 
Karakteristik & P value \\
Usia & 0,04 \\
Tingkat Pendidikan & 0,52 \\
Pekerjaan & 0,08 \\
Mendapatkan informasi kespro & 0,03 \\
sebelumnya & \\
\hline
\end{tabular}

Tabel 3 menunjukkan analisis karakteristik terhadap pengetahuan. Variabel usia dan mendapatkan informasi kespro sebelumnya memiliki nilai $p$ value 0,04 dan $0,03(<0,05)$, artinya bahwa usia dapat mempengaruhi peningkatan pengetahuan tentang kesehatan reproduksi. Variabel tingkat pendidikan dan pekerjaan memiliki nilai $p$ value 0,525 dan 0,082 $(>0,05)$, hal tersebut berarti bahwa tingkat pendidikan dan pekerjaan responden secara signifikan tidak mempengaruhi peningkatan pengetahuan kespro.

Pendidikan kesehatan reproduksi melalui seluler yang diberikan kepada pasangan calon pengantin dapat mempengaruhi peningkatan pengetahuan dan sikap kesehatan reproduksi. Perubahan pengetahuan antara kedua kelompok terjadi karena pada kelompok kontrol juga diberikan pendidikan kespro melalui kelas pra nikah. Namun peningkatan nilai rata-rata pada kelompok kontrol lebih rendah daripada kelompok intervensi. Artinya bahwa pemberian pendidikan kespro melalui kelas pranikah juga dapat meningkatkan pengetahuan responden tentang kespro namun hasilnya akan lebih maksimal apabila ditambah dengan pemberian pendidikan kespro melalui seluler. Pendidikan kespro melalui pesan whatsapp merupakan metode tambahan yang dapat meningkatkan pengetahuan lebih maksimal.

Peningkatan pengetahuan pasangan pengantin baru tersebut karena pada kelompok intervensi pemberian pendidikan kespro dilakukan melalui dua metode yaitu metode kelas pranikah dan melalui seluler. Pemberian informasi dengan lebih dari satu metode dianggap lebih efektif untuk meningkatkan pengetahuan seseorang. Jika diberikan dengan dua metode, responden dapat lebih memahami materi yang diberikan dibandingkan hanya dengan satu metode saja. Kelebihan dari pemberian pendidikan kespro melalui seluler atau whatsapp adalah pesan yang dikirimkan dapat dibaca berulang-ulang oleh responden dalam waktu yang berbeda. Selain itu, pesan melalui whatsapp yang diberikan juga disertai dengan gambar yang dapat mendeskripsikan isi pesan serta bahasa yang digunakan adalah bahasa sehari-sehari yang mudah dipahami.

Penelitian ini sejalan dengan hasil penelitian (L'Engle et al., 2016) ${ }^{10}$ yang menyatakan bahwa promosi kesehatan melalui pesan pada ponsel sangat dapat diterima oleh kalangan pemuda karena interaksi melalui seluler dapat terjaga kerahasiaannya, konten yang diberikan lebih sederhana dan informatif. Pemberian informasi kesehatan dan Infeksi Menular Seksual (IMS) melalui media seluler dapat meningkatkan pengetahuan 
responden tentang kespro dan IMS. ${ }^{11}$ Program olah pesan teks dapat menjadi metode yang efektif untuk meningkatkan pengetahuan kesehatan reproduksi. ${ }^{9}$

\section{KETERBATASAN PENELITIAN}

Keterbatasan penelitian ini adalah tidak semua pasangan calon pengantin mempunyai dan mampu menggunakan smartphone, sehingga pendidikan kespro hasilnya akan lebih maksimal apabila metode pemberian informasi diberikan melalui metode kombinasi antara pesan whatsapp dan kelas pra nikah.

\section{KESIMPULAN DAN SARAN}

Informasi kesehatan reproduksi yang diberikan melalui pesan whatsapp dapat meningkatkan tingkat pengetahuan yang lebih baik dibandingkan dengan pemberian informasi kespro melalui kelas pra nikah saja.

Perlu dilakukan penelitian selanjutnya dengan menggunakan metode penelitian mixed method agar mengetahui apakah responden merasa puas atau tidak dengan diberikannya pendidikan kespro melalui seluler tersebut.

\section{DAFTAR PUSTAKA}

1. Rokicki, S. et al. 2017. 'Impact of a text-messaging programon adolescent reproductive health: A cluster-randomized trial in Ghana', American Journal of Public Health, 107(2), pp. 298-305. doi: 10.2105/ AJPH.2016.303562.

2. Agarwal, S. et al. 2016. 'Guidelines for reporting of health interventions using mobile phones: Mobile health ( $\mathrm{mHealth}$ ) Evidence reporting and assessment
(mERA) checklist', BMJ (Online), 352, pp. 1-10. doi: 10.1136/bmj.i1174.

3. Kementerian Agama Kabupaten Sleman. 2018.

4. Wai, K. M. et al. 2015. 'Are husbands involving in their spouses' utilization of maternal care services?: A cross-sectional study in Yangon, Myanmar', PLoS ONE, 10(12), pp. 1-13. doi: 10.1371/journal. pone. 0144135 .

5. Chusna Aimma. 2017. Identifikasi Permasalahan Layanan Bimbingan Pranikah Di Kantor Urusan Agama Se-Kabupaten Sleman. Skripsi Fakultas IImu Pendidikan Universitas Negeri Yogyakarta. https:// core.ac.uk/download/pdf/158284300.pdf diakses pada tanggal 13 Agustus 2018

6. Miller, A. M. et al. 2015. 'Sexual rights as human rights: A guide to authoritative sources and principles for applying human rights to sexuality and sexual health', Reproductive Health Matters, 23(46), pp. 16-30. doi: 10.1016/j.rhm.2015.11.007

7. Ali, E.W.S., M. Eng, 2013. Step by Step Aplikasi Google Apps. Elex Media Komputindo

8. Terzioglu, F. et al. 2018. 'Sexual and Reproductive Health Education Needs, Gender Roles Attitudes and Acceptance of Couple Violence According to Engaged Men and Women', Community Mental Health Journal. Springer US, 54(3), pp. 354-360. doi: 10.1007/s10597-017-0227-3.

9. Lim, M. S. et al. 2014. 'Young people's comfort receiving sexual health information via social media and other sources', International Journal of STD and AIDS, 25(14), pp. 1003-1008. doi: 10.1177/0956462414527264.

10. L'Engle, K. L. et al. 2016. 'Mobile phone interventions for adolescent sexual and reproductive health: A systematic review', Pediatrics, 138(3). doi: 10.1542/ peds.2016-0884.

11. Brayboy, L. M. et al. 2017. 'Education to Adolescent Girls', journal of Pediatric and Adolescent Gynecology, 30(1), pp. 23-28. doi: 10.1016/j.jpag.2016.06.011. Girl. 